\title{
Effect of Canscora decussata Extract against the Neurochemical and Behavioral Changes Induced by 1-Methyl-4-Phenyl-1, 2, 3, 6-Tetrahydropyridine in Mice
}

\author{
Chitra V, Manasa K*, Tamilanban T, Narayanan J \\ Department of Pharmacology, SRM College of Pharmacy, SRM Institute of Science and Technology, Kattankulathur, Tamil Nadu, \\ INDIA.
}

\begin{abstract}
Objective: 1-Methyl-4-phenyl-1,2,3,6-tetrahydropyridine (MPTP) induced parkinsonism is a widely accepted animal model for screening the drugs used in Parkinson's disease (PD). In the present study, the neuroprotective effects of methanolic extract of Canscora decussata (MECD) were evaluated, which was already known for its monoamine oxidase inhibiting, antidepressant and anticonvulsant activities, a part from its use as a nerve tonic. Materials and Methods: Twenty four male Swiss albino mice were grouped into $4(\mathrm{n}=6)$. MECD at 100 and $200 \mathrm{mg} / \mathrm{kg}$ doses, 30 minutes before the MPTP $(20 \mathrm{mg} / \mathrm{kg}$, intraperitoneal administration) treatment were administered for 7 days and behavioral assessment was made by rota rod test, grip strength test, spontaneous locomotor activity and catatonia behavioral study. In addition, assessment of antioxidant enzymes such as SOD, CAT, GPx and GSH was done to know the neurotoxicity of MPTP. Results: The results indicated that MECD shows a significant improvement $\left({ }^{*} P<0.05\right)$ in the behavioral activities, striatal neurotransmitter content and antioxidant status in a dose dependent manner and significantly $(P<0.05)$ decreased the TBARS levels. Conclusion: The results obtained in this study indicate the antioxidant and neuroprotective role of MECD. Hence, Canscora decussata seems to have anti-Parkinson's activity in mice. Key words: Parkinson's disease, Canscora decussata, Substantia nigra, Dopamine.
\end{abstract}

Key words: Parkinson's disease, Canscora decussata, Substantia nigra, Dopamine.

\section{INTRODUCTION}

Parkinson's disease (PD) is a progressive neurodegenerative disorder with loss of dopamine carrying neurons in substantia nigra and is dominated by four cardinal signs: tremors, bradykinesia, rigidness and postural inability. Other neurobehavioral abnormalities include-personality changes (apathy, lack of confidence, fearful, anxiety), dementia, depression, sleep disturbance, sexual abnormality, lack of facial expression, impaired swallowing, decreased arm swing and other automated movements, small handwriting. ${ }^{1}$ It has been proved due to oxidative stress, neuronal death in PD occurs resulting from free radical damage, ${ }^{2,3}$
Generally, a combination therapy of synthetic drugs is more effective in treating PD. But the prolonged usage of this drugs leads to adverse complications like abnormal movements, behavioral effects, fluctuation in motor performance, hallucinations, hypotension, confusion, etc., ${ }^{4}$ Hence, now a day herbal treatment has gained a lot of importance in PD which minimize the side effects and provide desired results. More than 120 traditional medicines are being used for the therapy of CNS disorders in Asian countries. $^{5}$

Canscora decussata (Shankapushpi) has its used as a nervine tonic in ayurvedic
Submission Date: 02-03-2017; Revision Date: 16-05-2017; Accepted Date: 19-07-2017

DOI: 10.5530/ijper.52.1.10 Correspondence: Manasa K, Research Scholar, Department of Pharmacology, SRM College of Pharmacy, SRM Institute of Science and Technology, Chennai, Tamil Nadu, INDIA.

Phone No: 9952446996 E-mail Id: k.manasa1@ gmail.com

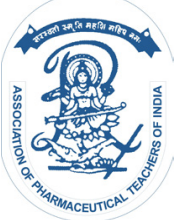

www.ijper.org 
medicine. Studies proved it also has anticonvulsant. ${ }^{6}$ monoamine oxidase inhibiting, spermicidal, antiinflammatory, anti-mycobacterium tuberculosis properties. The methanolic extract of Canscora decussata whole plant has been proved for its monoamine oxidase inhibiting activity. ${ }^{7}$ previously and now it was used to find its role in enhancing the dopaminergic transmission and antioxidant capacity in PD.

\section{MATERIALS AND METHODS}

\section{Animals}

Twenty four male Swiss albino mice (Mus musculus) of 25-35 g weight were procured from King's Institute, Guindy. In accordance to the IAEC guidelines, the mice were placed under standard laboratory conditions with a room temperature of $25 \pm 1^{\circ} \mathrm{C}$ and $60 \%$ humidity and balanced diet with water was provided to the test animals. The project proposal was approved by Institutional Animal Ethical Committee (IAEC 95/2009).

\section{Preparation of plant extract}

The whole plant of Canscora decussata were obtained from Thirunelveli district in Tamil nadu and authentication (Voucher specimen number-PARC/2010/500) was done by Prof. Jayaraman.P, Ph.D., Plant Anatomy Research Centre, Tambaram, Chennai -45. The Plants were cleaned, air dried and powdered in an automix blender and deep frozen. The powder is defatted with petroleum ether and extracted using methanol as solvent in Soxhlet apparatus for $72 \mathrm{~h}$, at a temperature of $45^{\circ} \mathrm{C}$ and the extract was concentrated in a rotary evaporator.

\section{Experimental design}

Twenty four animals were divided into four groups $(\mathrm{n}=6)$. Group I is Normal Control and given 10\% Tween 80 (p.o).Group II is given MPTP $(20 \mathrm{mg} / \mathrm{kg}$, i.p., four injections at $2 \mathrm{~h}$ intervals). Groups III and IV animals received $100 \mathrm{mg} / \mathrm{kg}$ and $200 \mathrm{mg} / \mathrm{kg}$ MECD (p.o) respectively, before $30 \mathrm{~min}$ to the first injection of MPTP each day during the seven days of the experimental period.

After the seven days of treatment, all the 4 groups underwent the motor integration tests. Cervical decapitation was performed and the striatal samples were separated by isolating the brain, homogenized in ice cold phosphate buffer saline solution and used for biochemical assessments.

\section{Rotarod test}

An Automated rotarod (Inco) was used to measure the motor coordination on the seventh day. The animals were left on a rotating rod at a speed of $10 \mathrm{rpm}$ at $5 \mathrm{~min}$ interval and underwent 10 trails before the initiation of the experiment. The control mouse remained on the rod for $180 \mathrm{sec}$. In the same manner, the time of the fall from the rod was noted with a cut-off time of $3 \mathrm{~min}^{8}$

\section{Grip strength test}

Male mice with an average weight of $18-30 \mathrm{~g}$ were used in this study. The animals were placed on a metallic wire suspended $30 \mathrm{~cm}$ above the floor on which they immediately grasp with the forepaws and then were released to hang. The animals with an ability to climb up the wire in $5 \mathrm{~s}$ were selected for the experiment and were tested every $15 \mathrm{~min}$. The animals unable to touch the threat with their hind limbs within $5 \mathrm{~s}$ or fall off from the metallic wire were considered to be impaired. ${ }^{9,10}$

\section{Spontaneous Locomotor Activity}

The animals when individually placed in the activity cage of the Actophotometer, moves and interrupts a beam of light falling on the photo cell and a count was recorded as the "basal activity score". After $30 \mathrm{~min}$ and $60 \mathrm{~min}$ of the oral administration of the vehicle or Standard or extract, each mouse was retested for activity for $10 \mathrm{~min}$ and the difference in the basal activity was recorded. Finally percentage decrease in the locomotor activity was calculated. ${ }^{11}$

\section{Catalepsy behavioral study}

The animals were left on a flat horizontal surface with both hind limbs on a square wooden block $3 \mathrm{~cm}$ height), latency to move was calculated in seconds. Haloperidol was used to induce the catatonia effect and the stages were studied at 30,60, 90 and $120 \mathrm{~min}$ after administration of the extract. In stage I, the animal remains immobile, only a slight push causes brief movements (score-0). In stage II, even a push no longer causes movements in the animal (score-0.5).In stage III, forelimbs of the animal were placed on a block $3 \mathrm{~cm}$ high and still it doesn't make any movements (score-1). In stage IV, one of its forelimb is placed on a block of $9 \mathrm{~cm}$ high and the other forelimb is allowed to hang free and the animals maintains a fixed position (score-2). ${ }^{12}$

\section{Beam Walking Assay}

Initially the mice were made to walk on a beam of $80 \mathrm{~cm}$ long, $3 \mathrm{~cm}$ wide, elevated $30 \mathrm{~cm}$ with metal supports to a goal box .After 30 min of standard and test treatments, the mouse was placed at one end of the beam and let to walk to the goal box. If the mice fall-off, they were once again placed on it for a maximum time of 60 seconds. As a measure of motor coordination deficit, the number of foot slips of one or both hind limbs was taken into consideration. ${ }^{13}$ 
Estimation of Dopamine, DOPAC (3, 1-dihydroxy phenylacetic acid) and HVA (Homovanillic acid) levels

The dissected brain samples were weighed, frozen at $80^{\circ} \mathrm{C}$ until the assay and homogenized in $1 \mathrm{ml}$ ice-cooled $0.1 \mathrm{mmol} / \mathrm{L}$ Perchloric acid solution containing $0.2 \mu \mathrm{g} / \mathrm{ml}$ L-isoproterenol hydrogen and $0.1 \mathrm{mmol} / \mathrm{L}$ EDTA. Tissue homogenates were centrifuged at $15000 \times \mathrm{g}$ at $4^{\circ} \mathrm{C}$ for $30 \mathrm{~min}$ and the supernatant was filtered and stored at $-80^{\circ} \mathrm{C}$ until assay. HPLC with an electrochemical detector and $25 \mathrm{~cm} \times 0.5 \mathrm{~cm}$ I.D column used in the assessment of Dopamine, 3'4-Dihydroxyphenyl acetic acid (DOPAC) and Homovanillic acid (HVA) levels. The sample peak obtained is compared with the standard peak and expressed in microgram per gram of tissue weight. ${ }^{14}$

\section{Estimation of Lipid peroxidation}

To one milliliter of tissue homogenate, 30\% trichloroacetic acid and $1 \mathrm{ml}$ of $0.8 \%$ thiobarbituric acid reagent were added and centrifuged at $3000 \mathrm{rpm}$ for $15 \mathrm{~min}$. The absorbance of the supernatant was read at $535 \mathrm{~nm}$ at room temperature against the blank. ${ }^{15}$

The content of Thiobarbituric acid reactive substances (TBARS), expressed as " $n$ " moles formed per milligram of protein in the tissue, was calculated.

\section{Assay of Superoxide dismutase (SOD)}

SOD was assessed by the inhibition of formation of $\mathrm{NADH}$-phenazine methosulphate nitroblue tetrazolium formazon. Nicotinamide adenine dinucleotide (NADH) was assessed after $90 \mathrm{~s}$ of incubation and the reaction was terminated by the addition of glacial acetic acid. The colour formed as the end point of the reaction was extracted in to the butanol layer and measured at $520 \mathrm{~nm}^{16}$

\section{Assay of Catalase (CAT)}

The tissue was homogenated in isotonic buffer $(\mathrm{pH} 7.4)$ and centrifuged at $1000 \times \mathrm{g}$ for ten min. Twenty microliter of 100 -fold diluted tissue supernatant added to $980 \mu 1$ of the assay mixture; the assay mixture consists of $900 \mu$ lof $10 \mathrm{mmol} / \mathrm{L}$ of $\mathrm{H}_{2} \mathrm{O}_{2}, 50 \mu \mathrm{l}$ of Tris $\mathrm{HCl}$ buffer $(\mathrm{pH}-8)$ and $30 \mu \mathrm{l}$ of water. The degree of decomposition of $\mathrm{H}_{2} \mathrm{O}_{2}$ was monitored spectrophotometrically at $240 \mathrm{~nm} \cdot{ }^{17}$

\section{Assay of Glutathione peroxidase (GPX)}

Hundred microliter of the diluted tissue was incubated at $37^{\circ} \mathrm{C}$ with reaction mixture consisting of $0.2 \mathrm{ml}$ of each EDTA, sodium azide and $\mathrm{H}_{2} \mathrm{O}_{2}$. Five hundred microliter of Trichloroacetic acid (TCA) was added to this mixture to stop the reaction and then centrifuged at $2000 \mathrm{rpm}$. Four milliliter of disodium hydrogen phosphate and $0.5 \mathrm{ml}$ Dithiobis (2-nitrobenzoic acid) (DTNB) were added to $0.5 \mathrm{ml}$ of supernatant and the colour formation was recorded at $420 \mathrm{~nm}$ in a spectrophotometer. ${ }^{18}$ Activity was expressed as $\mu$ moles of glutathione oxidized/minutes/mg protein.

\section{Assay of Reduced glutathione (GSH)}

To two milliliter of the tissue homogenate and $\mathrm{KCl}$ mixture, add $4 \mathrm{ml}$ of cold distilled water and $1 \mathrm{ml}$ of $50 \%$ TCA .The contents were centrifuged at 3000rpm for $15 \mathrm{~min}$ and from this $2 \mathrm{ml}$ of the supernatant was collected and $4 \mathrm{ml}$ of $0.4 \mathrm{M}$ Tris buffer $(\mathrm{pH}$ 8.9) and $0.1 \mathrm{ml}$ of $0.01 \mathrm{M} \mathrm{DTNB}$ were added, the absorbance was read $412 \mathrm{~nm}$ against the blank reagent. For blank readings, $2 \mathrm{ml}$ of distilled water was used in the place of tissue homogenate.

Total glutathione was calculated using the formula:

$$
\mathrm{Co}=(\mathrm{A} * \mathrm{D}) / \mathrm{E}
$$

Where $A$ is absorbance at $412 \mathrm{~nm}, \mathrm{D}$ is dilution factor, and $\mathrm{E}$ is the molar extinction coefficient

( $\left.\mathrm{C}=13000 \mathrm{M}^{-1} \mathrm{CM}^{-1}\right)$; $\mathrm{Co}$ is the concentration of $\mathrm{GSH} .{ }^{19}$

\section{2, 2 diphenyl 2 picryl hydrazyl hydrate (DPPH) Radical Scavenging Assay}

This method is a slight modification for Brand-Williams et al method (1995). ${ }^{20}$ The principle of this assay is DPPH reacts with an antioxidant compound, undergoes reduction which can be measured as the colour change at $517 \mathrm{~nm}$ using UV visible spectrophotometer. DPPH solution in methanol at $6 \times 10-5 \mathrm{M}$ concentration was freshly prepared during the assay procedure. Three $\mathrm{ml}$ of this solution was mixed with $100 \mathrm{microgram} / \mathrm{ml}$ concentration of MPTP and individual plant extracts (100mg/kg and $200 \mathrm{mg} / \mathrm{kg}$ MECD) as well. The samples were kept in the dark for 15 min at room temperature and the decrease in absorbance was measured.

Radical scavenging activity was calculated by the following formula.

$$
\% \text { Inhibition }=[(\mathrm{A} B-\mathrm{A} A) / \mathrm{A} B] \times 100
$$

Where $A B=$ absorption of blank sample $(t=0 \mathrm{~min})$ $\mathrm{A}_{\mathrm{A}}=$ absorption of test extract solution $(\mathrm{t}=15 \mathrm{~min}) \cdot{ }^{21}$

\section{Statistical Analysis}

The statistical analysis was carried out using analysis of variance (ANOVA) followed by Dunnet's test. P values $<0.05$ was considered as significant.

\section{RESULTS}

Figure 1 shows the rotarod test result. The retention time was decreased by MPTP with a significant $(\mathrm{P}<0.05)$ improvement in MECD treated groups. 


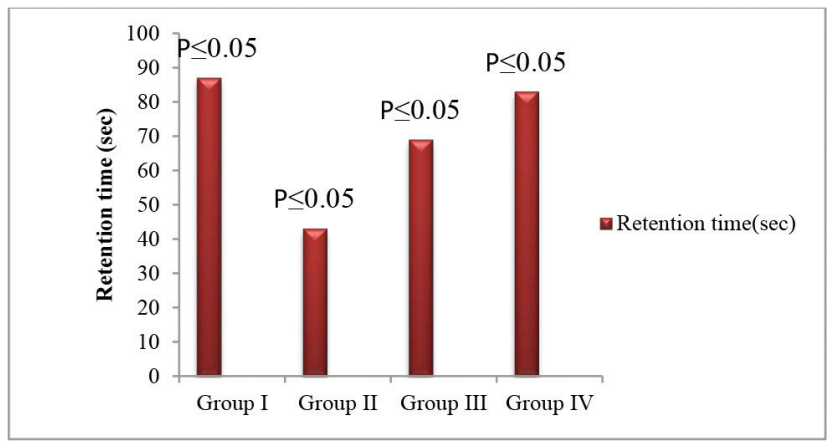

Figure 1: Effect of Mecd on Rotarod Test.

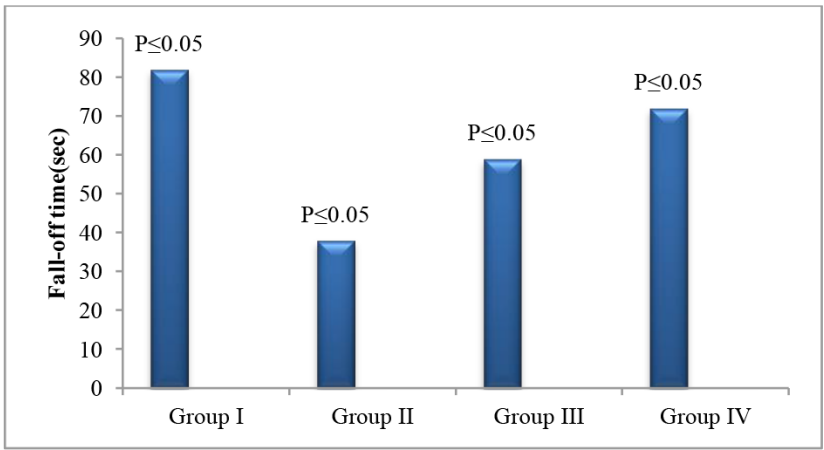

Figure 2: Effect of Mecd on Grip Strength Test.

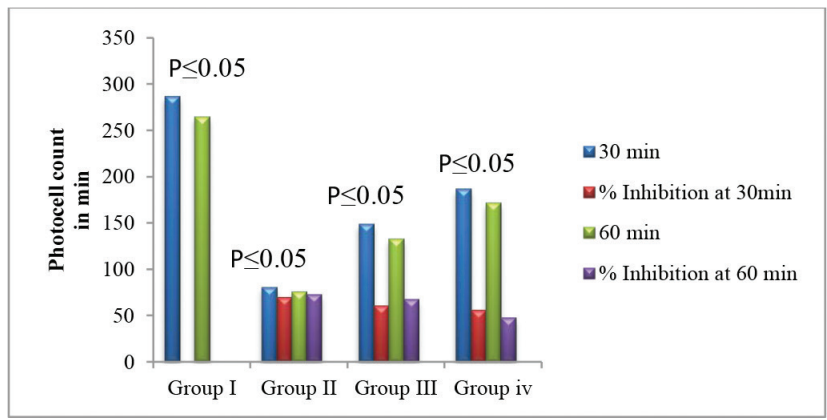

Figure 3: Effect of Mecd on Spontaneous Locomotor Activity.

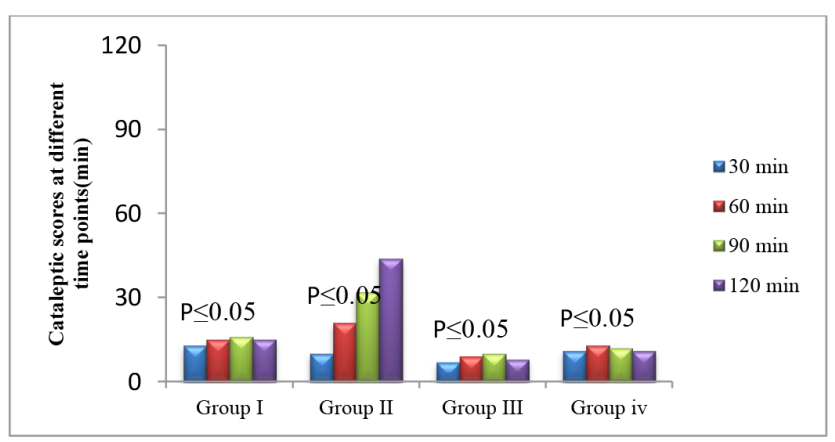

Figure 4: Effect of Mecd on Catatonia Behavioural Study.

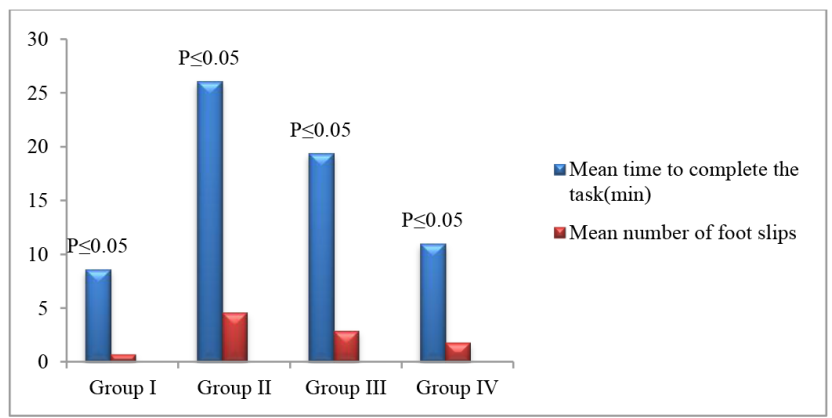

Figure 5: Effect of Mecd on Beam Walking Assay.

Figure 2 shows the results of Grip strength test. The fall off-time was reduced in the MPTP group and it was significantly $(\mathrm{P}<0.05)$ improved by MECD treatment.

Figure 3 shows the results of Spontaneous Locomotor activity using Actophotometer. In this test, MECD treated groups showed a significant $(\mathrm{P}<0.05)$ increase in the photocell count which was decreased significantly in MPTP group than the normal control group count.

The cataleptic score was increased in MPTP group after 60 and 90 min of administration. The score was significantly $(\mathrm{P}<0.05)$ reduced after $60 \mathrm{~min}$ with the test drug MECD at both doses tested $(100 \mathrm{mg} / \mathrm{kg}$ and $200 \mathrm{mg} / \mathrm{kg}$ ) (Figure 4).This reduction was significant through the period of observation, till 120 min. Maximum reduction in cataleptic activity was seen in $200 \mathrm{mg} / \mathrm{kg}$ treated group out the observation period.

The results of Beam walking assay were depicted in Figure 5. In Beam walking assay, the number of foot slips made by mice has been found to be a sensitive measure at determining MPTP-induced motor coordination deficits which was significantly $(\mathrm{P}<0.05)$ improved my MECD at both doses $(100 \mathrm{mg} / \mathrm{kg}$ and $200 \mathrm{mg} / \mathrm{kg}$ ).

Table 1 shows the Dopamine, DOPAC and HVA levels which were decreased in MPTP treated group and were significantly $(\mathrm{P}<0.05)$ increased on MECD treatment, especially at $200 \mathrm{mg} / \mathrm{kg}$ dose.

Striatal TBARS and antioxidant status are presented in Table 2. The striatal TBARS shows an elevation in MPTP treated group of mice when compared to control group. SOD, CAT, GPx and GSH activities were reduced in MPTP treated group when compared to control animals and were again restored significantly $(\mathrm{P}<0.05)$ on treatment with MECD at $100 \mathrm{mg} / \mathrm{kg}$ and $200 \mathrm{mg} / \mathrm{kg}$ doses.

Table 3 has proved that $200 \mathrm{mg} / \mathrm{kg}$ MECD shown antioxidant capacity $(\mathrm{P}<0.05)$ when assayed using DPPH. The results were compared with Vitamin $\mathrm{C}$ as a standard. 


\begin{tabular}{|c|c|c|c|c|}
\hline \multicolumn{5}{|c|}{ Table 1: Effect of Mecd on Dopamine, Dopac and HVA Levels. } \\
\hline \multirow{2}{*}{$\begin{array}{c}\text { Group } \\
(n=6)\end{array}$} & $\begin{array}{c}\text { Dose } \\
(\mathrm{mg} / \mathrm{kg})\end{array}$ & Dopamine & DOPAC & HVA \\
\cline { 3 - 5 } & $10 \%$ Tween80 & $11.84+0.06$ & $2.73+0.02$ & $1.37+0.02$ \\
\hline Normal & 20 & $3.72+0.01^{* \mathrm{a}}$ & $1.26+0.15^{* \mathrm{a}}$ & $0.51+0.01^{* \mathrm{a}}$ \\
\hline MPTP & $100+20$ & $4.82+0.14^{* \mathrm{~b}}$ & $1.68+0.04^{* \mathrm{~b}}$ & $0.76+0.01^{\text {tb }}$ \\
\hline MECD+MPTP & $200+20$ & $8.90+0.18^{* \mathrm{~b}}$ & $1.94+0.01^{* \mathrm{~b}}$ & $0.98+0.05^{\text {b }}$ \\
\hline MECD+MPTP & &
\end{tabular}

A-compared with Group-I, b-compared with Group-II, *P<0.05

\begin{tabular}{|c|c|c|c|c|c|c|}
\hline $\begin{array}{l}\text { Groups } \\
(n=6)\end{array}$ & $\begin{array}{c}\text { Dose } \\
(\mathrm{mg} / \mathrm{kg})\end{array}$ & $\begin{array}{c}S O D \\
(\mu / m g \text { protein })\end{array}$ & $\begin{array}{c}L P O \\
\text { (n moles/mg } \\
\text { protein) }\end{array}$ & $\begin{array}{c}C A T \\
(\mu / m g \text { protein })\end{array}$ & $\begin{array}{c}G P x \\
(\mu / m g \text { protein) }\end{array}$ & $\begin{array}{c}\text { GSH } \\
(\mu / m g \text { protein })\end{array}$ \\
\hline Control & - & $4.23+0.76$ & $2.56+0.04$ & $0.51+0.01$ & $14.28+0.15$ & $0.69+0.04$ \\
\hline MPTP & 20 & $1.96+0.12^{* a}$ & $4.39+0.07^{* a}$ & $0.16+0.04^{* a}$ & $7.79+0.09^{* a}$ & $0.22+0.06^{* a}$ \\
\hline MECD+MPTP & $100+20$ & $2.38+0.31^{* b}$ & $3.86+0.01^{* b}$ & $0.28+0.04^{* b}$ & $10.72+0.12^{* b}$ & $0.39+0.01^{* a}$ \\
\hline MECD+MPTP & $200+20$ & $3.88+0.26$ bb & $2.92+0.04$ b & $0.47+0.02^{* b}$ & $12.13+0.23^{* b}$ & $0.60+0.04^{* b}$ \\
\hline
\end{tabular}

a- compared with control group, b-compared with MPTP Group, *P<0.05

$\mu$ : Number of moles of antioxidant enzyme/ $\mathrm{mg}$ protein

\begin{tabular}{|c|c|c|c|}
\hline \multicolumn{4}{|c|}{ Table 3: Evaluation of Anti Oxidant Activity of Mecd Using Dpph Assay. } \\
\hline $\begin{array}{c}\text { Group } \\
(n=6)\end{array}$ & $\begin{array}{c}\text { Dose } \\
(\mathrm{mg} / \mathrm{kg})\end{array}$ & $\begin{array}{c}\text { Concentration } \\
(\mu \mathrm{g} / \mathrm{m} /)\end{array}$ & $\%$ Inhibition $^{*}$ \\
\hline Normal & $10 \%$ Tween80 & 100 & $61.45+0.28$ \\
\hline MPTP & 20 & 100 & $17.54+1.39^{\mathrm{a}^{*}}$ \\
\hline MECD+MPTP & $100+20$ & 100 & $36.81+1.56$ \\
\hline MECD+MPTP & $200+20$ & 100 & $43.96+2.59^{\mathrm{b}^{* *}}$ \\
\hline Std Vitamin C & - & 100 & $72.18+0.67$ \\
\hline
\end{tabular}

A-compared with Group-l, b-compared with Std Vit C, *P<0.05

\section{DISCUSSION}

Recent investigations on MPTP induced neurotoxicity shows that this might be a toxic responsible for secondary (acquired) Parkinsonism. ${ }^{22} \mathrm{MPP}^{+}$, an active metabolite of MPTP gets accumulated with in the substantia nigra and inhibits ATP production leading to superoxide radical formation. These radicals react with $\mathrm{NO}$ to produce peroxynitrite causing nitration of tyrosine hydroxylase and consequently inhibits dopamine production. ${ }^{23}$ MPTP has similar effects like paraquat (PQ; 1, 1'-dimethyl-4, 4'-bipyridinium), which has structural similarity to $\mathrm{MPP}^{++}$

PD will be characterized predominantly by its motor symptomology and cognitive defects. ${ }^{24}$ hence, the present study provides evidence to the behavioral and biochemical changes caused by MPTP. Also, it shows the quantitative behavioral responses in MPTP treated animals to the administration of plant extract (MECD) in a dose dependent manner.
MPTP mice showed a declined performance in rotarod test due to motor incoordination. MECD administration improved the retention time on the rod which shows that it had a beneficial effect on MPTP caused motor declination. In Beam walking assay, foot slips made by the mice has been found to be a sensitive measure of determining MPTP-induced motor coordination deficits which was improved my MECD at $100 \mathrm{mg} / \mathrm{kg}$ and $200 \mathrm{mg} / \mathrm{kg}$ doses. The striatum is known to be involved in head and forelimb motor control. Altered behavioral responses in mice, following DA depletion or striatal damage, is considered to be similar to human Parkinsonism. ${ }^{25}$

Grip strength test was done to estimate the muscle coordination. MPTP administration shows a decrease in the fall-off time when compared to the control group. MECD successively improved the muscle coordination and strength.

It is documented that locomotor activation results from brain activation, due to the excitation of central neurons 
and increase in cerebral metabolism. Dopamine (DA) plays an essential role among the neurochemical metabolisms involved in brain activation. ${ }^{26}$ MPTP reduces the brain activity by decreasing the dopaminergic neurons. MECD treatment at both doses $(100 \mathrm{mg} / \mathrm{kg}$ and $200 \mathrm{mg} / \mathrm{kg}$ ) significantly increased the photocells count which shows an improvement in the locomotor activity. MPTP also induce catatonic response. Maximum cataleptic store is observed after 60 and $90 \mathrm{~min}$ of administration. The score was significantly reduced after 60 min with the test drug MECD at both doses tested $(100 \mathrm{mg} / \mathrm{kg}$ and $200 \mathrm{mg} / \mathrm{kg})$.

The free radicals production can be inactivated by free radical scavenging system. ${ }^{14}$ In $\mathrm{PD}$, substantia nigra is conductive to the formation of cytotoxic free radicals. These free radicals cause lipid peroxidation and cell death, which shows that it leads to a severe oxidative state in SN. Increased oxidative stress leads to over consumption of SOD and GPX. ${ }^{27}$ In the present study, the decreased level of reduced glutathione in MPTP treated experimental group indicates an increased generation of free radicals and the reduced glutathione was depleted during the process of oxidative stress. ${ }^{28,29}$ Thus, anti-oxidative ability of dopamine neurons was reduced obviously, which induce consequent cell death of nigrostriatal dopaminergic neurons. ${ }^{30}$ Consequently, there had been a significant improvement in the levels of SOD, Catalase and glutathione peroxidase enzyme levels in the MECD treated mice. The antioxidant status in $200 \mathrm{mg} / \mathrm{kg}$ MECD group is equal to the normal group animals range.

DPPH is a stable free radical which can be dissolved in methanol or ethanol and shows characteristic absorption at $516 \mathrm{~nm}$ when the free radicals were scavenged by antioxidant present in the plant extract or test drug. ${ }^{31}$ The free radical scavenging activity was measured as "percentage inhibition value". MECD at $200 \mathrm{mg} / \mathrm{kg}$ dose shows a significant percentage of inhibition and proved to have antioxidant capacity. The absorbance value of the extracts were compared with that of Vitamin C value (standard).

In the MPTP mice, a significant reduction of striatal dopamine and its metabolites was observed. The dopamine content shows a rise after MPTP intoxication in mice. The striatal dopamine loss was at least partially prevented when mice were treated with MECD at both doses and the beneficial effect was maximum for $200 \mathrm{mg} / \mathrm{kg}$ dose. It has been reported that MAO inhibition was evident with Canscora decussata extract up on the presence of mangiferin, a 16 membered xanthone of Gentianaceae family ${ }^{32}$ Possibly due to monoamine oxidase inhibition, it can be said that the dopamine level enhancing is assured by this plant extract. In the present study, MECD reduced the MPTP induced lipid peroxidation (TBARS), SOD, Catalase and brain glutathione levels than the normal range. These levels were significantly improved on MECD treatment. In conclusion, it can be proved that MECD can be employed in the treatment of PD due to its neuroprotective and antioxidant properties.

\section{ACKNOWLEDGEMENT}

Authors are thankful to the Dean and Vice-Principal, SRM College of Pharmacy and management of SRM University for providing necessary facilities to carry out this work.

\section{CONFLICT OF INTEREST}

The authors declare that they have no conflict of interest.

\section{ABBREVIATIONS USED}

PD: Parkinson's Disease; MECD: Methanolic extract of Canscora decussata; GSH: Reduced Glutathione; DPPH: 2,2 Diphenyl 2 picryl hydrazyl hydrate.

\section{REFERENCES}

1. Bennett, Plum. Cecil Text book of Medicine. $20^{\text {th }}$ ed: Prism India Pvt. Ltd,1996; p.2042-2046.

2. Jenner P. Oxidative stress in Parkinson's disease. Annals of Neurology. 2003;53(3):26-36.

3. Kumar GP, Khanum Farhath. Neuroprotective potential of phytochemicals. Pharmacognosy Reviews. 2012;6(12):81-90.

4. Foley P, Riederer P. Influence of neurotoxins and oxidative stress on the onset and progression of Parkinson's disease.Journal of Neurology. 2000; 247(2):82-94.

5. Kumar GP, Anilakumar KR, Naveen S. Phytochemicals Having Neuroprotective Properties from Dietary Sources and Medicinal Herbs. Pharmacognosy Journal. 2015;7(1):1-17.

6. Dikshit SK, Tewari PV, Dixit SP. Anticonvulsant activity of Canscora decussata Roem and Schult. Indian Journal of Physiology and Pharmacology. 1972;16(1):81-83.

7. Bhattacharya SK, Sanyal AK, Ghosal S. Monoamino oxidase-inhibiting activity of Mangiferin isolated from Canscora decussata. Naturwissenschaflen. 1972;59(12):651.

8. Robert A.Turner. Screening methods in Pharmacology. London:Academic Press;1971:231.

9. Gerhard Vogel.H. Drug Discovery and Evaluation-Pharmacological assays ( $2^{\text {nd }}$ Ed). Springer; 2008:397.

10. Raj PV, Parasuraman S, Dhanaraj SA, Lee XY, Tan HL, Stephanie A/P Sandanasamy, Koay Chin Yin. Effect of Ganoderma lucidum on MPTP Induced Behavioral Alterations in Swiss Albino Mice. Journal of Young Pharmacist.2016;8(3):194-7.

11. Viswanatha GL, Nandakumar K, Shylaja H, Ramesh C, Rajesh S, Srinath R. Anxiolytic and Anticonvulsant activity of alcoholic extract of heartwood of Cedrus deodara Roxb. in rodents. Journal of Pharmaceutical Research and Health Care. 2009;1(2):217-39.

12. Nair V, Arjuman A, Dorababu P, Gopalakrishna HN, A.V.Chakradhar Rao and Mohan L. Effect of NR-ANX-C (a polyherbal formulation) on haloperidol 
induced catalepsy in albino mice. Indian Journal of Medical Research. 2007;126:480-4.

13. Magaji MG, Yaro AH, Adamu A, Yau J, Malami S, Abubakar Y, et al. Some neuro pharmacological studies on hydroalcoholic extract of Maeura angolensis DC(Caparidaceae) in mice and chickens. Journal of International environmental Application and sciences. 2009;3(3):14-21.

14. REN JP ,ZHAO YM, SUN XJ. Toxic influence of chronic oral administration of paraquat on nigrostriatal dopaminergic neurons in C57BL/6 mice.Chinese medical Journal. 2009; 122(19):2366-71.

15. Goel R, Goel A, Manocha A, K.K.Pillai,Rashmi S.Srivastava. Influence of Nebivolol on anticonvulsant effect of Lamotrignine. Indian Journal of Pharmacology. 2009;41(1):41-46.

16. Kakkar P, Das B, Viswanathan PN. Modified spectrophotometric assay of superoxide dismutase. Indian Journal of Biophysics. 1984;21:130-2.

17. Sinha AK. Colorimetric Assay of catalase. Analytical Biochemistry. 1972 ;47(2):389-94

18. Marklund $S$ and Marklund $G$. Involvement of superoxide anion radical in auto oxidation of pyrogallol and a convenient assay for the SOD. European Journal of Biochemistry. $1974 ;$ 47(3):469-74.

19. Brand-Williams W, Cuvelier ME, Berset CL. Use of free radicalmethod to evaluate antioxidant activity. Lebensm Wiss Technology.1995;28(1):25-30.

20. Senevirathne M, Kim SH, Siriwardhana N, Ha JH, Lee KW, Jeon YJ. Antioxidant potential of Ecklonia cava on reactive oxygen species, metal chelating, reducing power and lipid peroxidation inhibition. Food Science and Technology. 2006; 12(1):27-38.

21. Iqbal S, Sivaraj C, Gunasekaran K. Antioxidant and Anticancer Activities of Methanol Extract of Seeds of Datura stramonium I. Free Radicals and Antioxidants. 2017; 7(2): 184-9.
22. Joseph J. Dipiro, Robert Talbert L, Peggy Hayes E, Gary CY, Gary Matzke R, L.Micael Posey et al. Pharmacotherapy-A Pathophysiologic Approach. $2^{\text {nd }}$ ed: Appleton and Longe Publications. 1976;p.913-23.

23. Przedborski S, Jackson-Lewis V, Djaldetti R, Liberatore G, Vila M, Vukosavic $\mathrm{S}$, et al. The parkinsonian toxin MPTP:action and mechanism. Restorative Neurology and Neuroscience. 2000;16(2):135-42.

24. Prabhakar S, Syal P, Srivastava T. $P_{300}$ in Newly Diagnosed Nondementing Parkinson's Disease: Effect of Dopaminergic Drugs.Neurology India.2000;48(3):239-42.

25. Cousins MS, Salamone JD. Involvement of ventrolateral striatal dopamine in movement initiation and execution: a microdialysis and behavioral investigation. Neuroscience. 1996; 70(4):849-59.

26. Pandy Z, Jose N, Subhash H. CNS Activity of Methanol and Acetone extracts of Acorus calamus leaves in Mice. Journal of Pharmacology and Toxicology. 2009;4(2):79-86.

27. Reiter RJ. Melatonin: Lowering the high price of free radicals.News in physiological sciences. 2000;15(5):246-50.

28. Nithiya P, Mohan K. Antioxidant effect of Trichosanthes tricuspidate root extract on sildenafil induced migraine in albino rats. Pharmacognosy Research. 2009;1(6):402-5.

29. Schulz JB, Lindenau J, Seyfried J, Dichgans J. Glutathione, oxidative stress and neurodegeneration. European Journal of Biochemistry. 2000;267(16):4904-11.

30. Sudha K, Rao AV, Rao S, Rao A. Free radical toxicity and antioxidants in Parkinson's disease. Neurology India .2003;51(1):60-62.

31. Apak R, Kubilay G, Birsen D, Mustava O, Saliha EC, Burcu B et al. Comparative evaluation of various total antioxidant capacity assays applied to phenolic compounds with the CUPRAC assay. Molecules. 2007;12:1496-1547.

32. Shah KA, Patel MB, Patel RJ, Parmar PK. Mangifera Indica (Mango)- Review Article. Pharmacognosy Reviews. 2010;4(7):42-8.

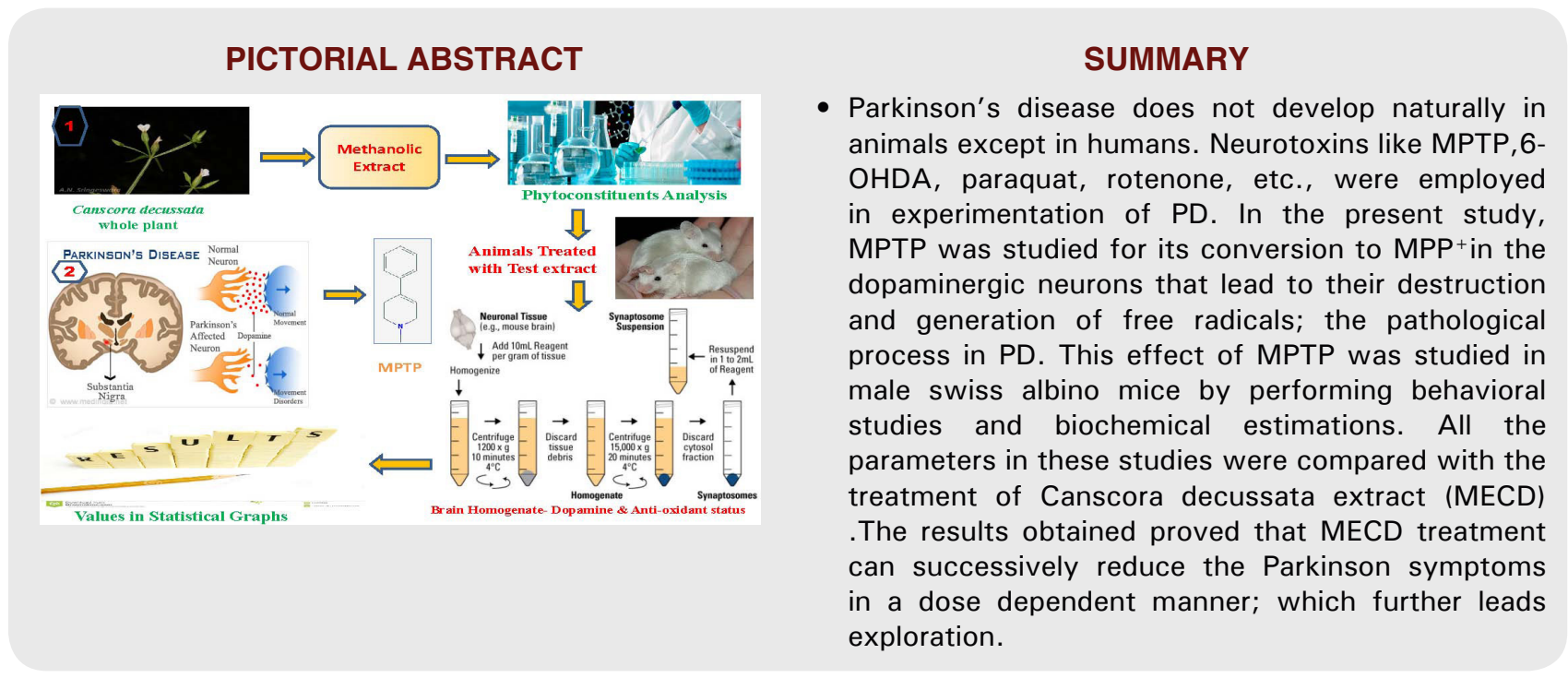

Cite this article: Chitra V, Manasa K, Tamilanban T, Narayanan J. Effect of Canscora decussata Extract against the Neurochemical and Behavioral Changes Induced by 1-Methyl-4-Phenyl-1, 2, 3, 6-Tetrahydropyridine in Mice. Indian $\mathrm{J}$ of Pharmaceutical Education and Research. 2018;52(1):87-93. 